\title{
Ulusal Mimarlık Sergisi Üzerinden Türkiye Mimarlığını Dönemsel Olarak Değerlendiren Bir Yöntem Önerisi
}

\author{
A Method Suggestion Through National Architecture Exhibition \\ For Evaluation of Turkish Architecture Periodically
}

Selin KARAiBRAHIMOĞLU, ${ }^{1}$ 을 Ayhan USTA²

ÖZ

Mimarlık; mekân tasarlamanın ötesinde, fiziksel, toplumsal ve kültürel çevreden, insandan ve ihtiyaçlarından etkilenen, böylece farklılaşan çok yönlü bir alandır. Dolayısıyla mimarlık, toplumsal alandaki her türlü gelişim, değişim ve dönüşümle sıkı bağ kuran, aynı zamanda değiştirme ve dönüştürme gücüne sahip somut bir üretim alanıdır. Bu nedenle bir toplumdaki mimari üretimi anlamak için öncelikle toplumsal yapının dinamiklerini çözümlemek gerekir. Bu kapsamla çalışmanın amacı Türkiye'de güncel mimarinin gelişimini, toplumsal yapının değişen-dönüşen dinamikleri ve bu dinamiklerin mimariye kazandırdığı yeni boyutlar üzerinden okumayı ve değerlendirmeyi olanaklı kılan bir yöntem önerisinin geliştirilmesi ve böylece mimarinin dönemsel olarak temsil ettiklerinin belirlenebilmesidir. Bu dönemsel değerlendirmeler Türkiye mimarlığını temsil etme niyeti taşıyan ve mimarinin kamusallaşmasını sağlayan, aynı zamanda Türkiye mimarlığına kaynaklık eden bir arşiv niteliği taşıyan “Ulusal Mimarlık Sergisi ve Ödülleri Kataloğu” üzerinden gerçekleştirilmiştir. Öte yandan değerlendirilen toplumsal yapı verileri nitel karaktere sahip sosyal bilimlerle ilişkili verilerdir. Dolayısıyla önerilen yöntem daha çok sosyal araştırmalarda kullanılan nitel araştırma yöntemleri üzerine kurgulanmıştır. Genel anlamda sistemlilik esasına dayanan yöntem; birbirini takip eden, verilerin toplanması, gruplanması, azaltılması, çakıştııılması ve tartışılmasını içeren, geri dönüşlere olanak sağlayan, gruplamatanımlama, özetleme-kodlama, çakıştırma-ilişkilendirme ve değerlendirme olarak tanımlanan dört aşamadan oluşmaktadır. Çalışmada bu aşamalar akış şeması üzerinde tanımlanmış, her aşama detaylandırılmış ve tek bir dönem kataloğu üzerinde örneklenerek açıklanmıştır.

Anahtar sözcükler: Toplumsal yapı; Türkiye mimarlığı; Ulusal Mimarlık Sergisi ve Ödülleri Kataloğu.

\section{ABSTRACT}

Beyond designing space, architecture is a versatile field which is influenced from physical, social and cultural environment, from people and their needs. Therefore, architecture is a tangible production field which has tight bonds with every kind of development, change and transformation in the society and at the same time has the power of changing and transforming. So in order to understand the architectural production in a society, first of all we need to analyse dynamics of social structure. In this scope, the aim of this study is to propose a method suggestion which enables evaluation of development of current architecture, changing-transforming dynamics of social structure and analyse them through new dimensions introduced to architecture and to determine the representations of architecture periodically. These periodical evaluations were carried out through "Catalogue of National Architecture Exhibition and Prizes" which has the aim of representing Turkish architecture and enable nationalization of architecture. The reason is that the event serves as a resource of Turkish architecture and has the archive attribute. On the other hand, these social structure data are related with social sciences and have qualitative characteristics. Therefore the method proposed was mostly arranged on qualitative research methods used in social researches. The method which is basically based on systematic is composed of four stages defined as grouping-defining, summary-coding, superposition and evaluation which includes gathering, grouping, decreasing, superposing and discussing subsequent data. In the study these stages were defined on flow chart, every stage was detailed and explained on each period catalogue with examples.

Keywords: Social structure; architecture of Turkey; National Architecture Exhibition and Awards Catalog.

Bu makale Karadeniz Teknik Üniversitesi Fen Bilimleri Enstitüsü Mimarlık Anabilim Dalı, Modernizm Bağlamında 2000'li Yıllarda Türkiye Mimarlığı; Ulusal Mimarlık Sergileri Üzerinden Bir Değerlendirmesi Doktora Tezi'nden (Ekim 2014), üretilmiştir.

'Giresun Üniversitesi, Teknik Bilimler Meslek Yüksekokulu, Mimarlık ve Şehir Planlama Bölümü, Giresun ${ }^{2}$ Istanbul Kültür Üniversitesi Mimarlık Fakültesi, Mimarlık Anabilim Dalı, İstanbul

Başvuru tarihi: 20 Mart 2018 - Kabul tarihi: 27 Şubat 2020

İletişim: Selin KARAIBRAHIMOĞLU. e-posta: selins80@yahoo.com

๑ 2020 Yıldız Teknik Üniversitesi Mimarlık Fakültesi - ๑ 2020 Yıldız Technical University, Faculty of Architecture 


\section{Giriş}

Mimarlık yaşamsal süreçlerden ayrılmıyor. Gelişmeler ve toplumsal döngü yaşama yansımakta gecikmiyor, mimarlığın da belirleyicisi oluyor. ${ }^{1}$

Hasol, 2017

Mimarlık hem zihinsel hem de fiziksel süreç içeren bir eylem olarak insan ve çevresi arasındaki ilişkiye müdahale etmektedir. İnsanın varoluşundan günümüze değin devam eden bu eylem, toplumsal alandaki gelişimden ve değişimden etkilenerek biçimlenmiştir. Dolayısıyla mimarlık bir toplumun politik, ekonomik ve sosyokültürel ortamını yansıtan, zamanla değişen somut bir yapıdır ve belli bir dönemin mimarlığı o dönemin toplumsal bileşenleri ile ilişkilendirilerek değerlendirilmelidir. Bu anlamda farklı coğrafyalarda olduğu gibi Türkiye'de de mimari; ülkenin politik, ekonomik ve sosyokültürel tarihine bağlı olarak değişen, kendine has dinamiklere sahip bir etkinlik alanı olarak irdelenmelidir.

Cumhuriyet'in ilk yıllarından itibaren yaratılmak istenen modern toplumsal yapının niteliği ile ilişkili olarak Türkiye'de mimarlık tartş̧maları genellikle modernite kavramı ekseninde gerçekleştirilmiştir. Öyle ki Cumhuriyet yönetimi mimariyi ve tanımladığı kentsel çevreyi toplumsal yapıdaki değişime katkı sağlayacak, modernizmi görünür kılacak bir araç olarak kabul etmiş; Habermas'ın (1994) belirttiği gibi toplumsal modernizm gelmeden estetik modernizm ithal edilmiştir. ${ }^{2} 2000^{\prime} l i$ yıllara değin devam eden süreçte ortaya çıkan ulusal ve uluslararası eğilimlerin de bu anlayışın ürünü olduğunu ve bu eğilimin günümüz mimari söylemini tanımlayan "bireysel çoğulcu" tutuma zemin hazırladığını söylemek mümkündür. ${ }^{3} \mathrm{Bu}$ anlamda Türkiye'de mimari her zaman toplumsal bir rol üstlenmiş, toplumsal yapıyı biçimlendiren her unsur beraberinde mimariyi de biçimlendirmiştir. Bu nedenlerle Türkiye'de mimariyi anlamak, anlamlandırmak, anlatmak istediklerini yorumlayabilmek ancak onu, ortaya çıktı̆ı dönemin dinamikleri içinde irdelemekle mümkün olabilir. Ancak 20. yy Türkiye mimarlık tarihi yazımına ilişkin araştırmalar, sınırlı da olsa, mimarinin yaşamsal süreçlerle ilişkisine değinse de güncel mimariye ve onun etki alanına ilişkin tartışmalar genellikle mimar-ürün, teknoloji-ürün, malzeme-ürün, biçim-ürün ya da kent-ürün ilişkisi üzerinden sadece simgesel değeri ya da biçimsel zenginliği üzerinden sürdürülmektedir. Oysa 2000 'li yıllardan itibaren ülke politik, ekonomik ve sosyokültürel açıdan önceki dönemlere görece daha farkIı bir görüntüye sahiptir. Bu farklılıkların başında kendisini muhafazakâr demokrat olarak tanımlayan, ancak kimi araştırmacının "Siyasal İslam" fikri ile özdeşleştirdiği, İslami ve muhafazakâr kimlikli bir siyasal partinin ilk defa, tek başına iktidara gelerek etkinlik kazanması ve bunu yirmi

\footnotetext{
1 Hasol 2017.
}

yıla yakın bir süredir devam ettirmesi sayılabilir. Bu zamansal süreklilik nedeniyle siyasal iktidarın ülkenin toplumsal yapısını oluşturan her alanda etkin bir role sahip olduğu söylenebilir. Öte yandan 2000 'li yıllardan sonra dünyanın hızla küreselleşmesi, her alanda hissedilen teknolojik gelişmeler, dolayısıyla gelişen iletişim teknolojileri bu dönemi farklı kılan diğer etkenler olarak dikkat çekmektedir.

Bu nedenlerle çalışmanın amacı Türkiye'de güncel mimarinin gelişimini, toplumsal yapının değişen, dönüşen dinamikleri ve bu dinamiklerin mimariye kazandırdığı yeni boyutlar üzerinden okumayı olanaklı kılan bir yöntem önerisinin geliştirilmesi ve böylece mimarinin dönemsel olarak temsil ettiklerinin belirlenmesidir. Çünkü soyut bir yorum ve ifade arayışı içindeki mimari aslında konuşmaktadır. ${ }^{4}$ Dolayısıyla mimarinin duyulması, başka bir ifade ile kamusallaşması mimarın ve mimarlığın gösterilmesi, görünürlük kazanması ile sağlanabilir. Bu da yapının sergi, bienal, yarışma, ödül, periyodik, yıllık vb. gibi ortamlarda yer almasıyla gerçekleşir. ${ }^{5}$ Bu etkinlikler içerisinde mimarlık ödüllerinin ve sergilerinin, mimarlık söyleminin şekillendirilmesindeki rolü farklıdır. Ulusal ve uluslararası boyutta düzenlenen mimarlık ödülleri, sergileri ve ilgili yayınlar, mimarinin kamusal ortamda paylaşılmasını sağlamanın yanı sıra, mimariyi yorumlayan ve yeniden üreten eleştirel eylemlerdir. ${ }^{6}$ Türkiye'de Cumhuriyet'in ilanından sonra sayıları artan mimarlık sergileri daha çok modern cumhuriyetin imarı kapsamında gerçekleştirilen, çoğunlukla yabancı mimarların katıldığı yarışmalar bünyesinde hazırlanmıştr. 1920'lerin sonlarından itibaren yarışma sayısında artış olmasına rağmen 1943 tarihli "Anıtkabir Proje Yarışması" gibi istisnalar dışında kamuoyuna gösterme işlevi taşıyan etkinliklere rastlanmamaktadır. 1980'lerin sonunda ilk “Ulusal Mimarlık Sergisi ve Ödülleri" etkinliği düzenlenene kadar, mimarinin gösterilme çabası oldukça sınırlı olmuş, mimarlık sergileri mimarlık okullarında kapalı olarak var olabilmişlerdir. ${ }^{7}$ Bu anlamda Ulusal Mimarlık Sergisi ve Ödülleri'nin Türkiye mimarlığının kamusallaşmasını sağlayan etkinlikler içerisinde ayrı bir yeri vardır. Etkinlik sonrasında basılan katalogların ise Türkiye mimarlığının 1988 'den beri ulaşthğı düzeyin belirlenmesine, mimarlık üretiminin değişim, gelişim ve üretiminin izlenmesine, kamuoyuna sunularak toplumun mimarlık bilincinin geliştirilmesine ve çağdaş birikiminin mercek altına alınmasına olanak tanıdığını ${ }^{8}$ söylemek mümkündür.

Mimariye ilişkin değerlendirmelerin genellikle üretilen yapılar ve tasarımlar üzerinden yapılıyor olması çalışmada bir mimari üretim arşivinin incelenmesini gerektirmiştir. Bu nedenle önerilen yöntem, Türkiye mimarlığına ilişkin önemli bir kaynak oluşturan ve bu özelliği ile dönemsel değerlendirme yapmaya olanak sağlayan "Ulusal Mimarlık

\footnotetext{
4 Akyıldız 2007.

5 Tanyeli 2005.

8 Kahvecioğlu 2011.

6 Balamir 2005.

Tanyeli 2005.
} 
Sergisi ve Ödülleri Kataloğu" üzerine kurgulanmışttr. Öte yandan yöntemin bileşenleri olarak tanımlanan toplumsal yapı verilerinin nitel karaktere sahip olması; yöntemin nitel araştırma yöntemleriyle çözümlenmesini gerekli kılmış, dolayısıyla çalışmada nitel bir yöntem önerisi sunulmuştur. Bu kapsamda öncelikle önerilen yöntemin uygulama alanı, bileşenleri, sınırlılıkları, ölçütleri ve genel kurgusu tanımlanmış, sonrasında geliştirilen yöntem önerisi bir döneme ait "Ulusal Mimarlık Sergisi ve Ödülleri Kataloğu" üzerinden örneklendirilerek sınanmıştır. ${ }^{9}$

\section{Yöntem Üzerine}

Toplumsal değişmeyi anlamaya yönelik sıralanabilecek pek çok araştırma yönteminden biri nitel araştırmalardır. ${ }^{10}$ Bu bağlamda mimari mekânın üretiminde mimarın yaratıcı etkinliğinin dışında toplumsal olayların, sosyal olayların, ve dönemsel koşulların belirleyici oluşu çalışma kapsamında tasarlanan yöntemin nitel veri analizi üzerine kurgulanmasını gerekli kılmıştır. Nitel araştırmalar, incelediği probleme ilişkin sorgulayıcı, yorumlayıcı ve problemin doğal ortamındaki biçimini anlama uğraşı içinde olan, ${ }^{11}$ algı ve olayların doğal ortamda, gerçekçi ve bütünlüğü bozulmadan gözlenmesine odaklanan nitel bir sürecin izlendiği araştırmalardır. ${ }^{12} \mathrm{Bu}$ araştırmalarda analizler, nicel araştırmalarda olduğu gibi standart süreçlerde gerçekleştirilemez. Çünkü nitel araştırmaların esası sistemliliktir ve tanımlanmış bir problem vardır. Demirli (2007) bu problemin araştıııması için bir araştırma deseni geliştirildiğini belirtir; bu desen gereği veriler toplanır, analiz edilir, bulgulara ulaşılır ve raporlanır. ${ }^{13}$ Nitel araştırmalarda veri analizi sosyal dünya düzeninin araştırılmasında kullanılan en yaygın yöntem olan ${ }^{14}$ tümevarıma dayanır. Bu kapsamla çalışmada önerilen yöntem genel olarak nitel araştırmaya dayalı tümevarım olarak tanımlanabilir ve en genel anlamda sistemlilik üzerine kurgulanmıştır. Bu nedenle yöntemin aşamaları tanımlanmadan önce, bu sistematik düzeni etkileyen; yöntemin uygulama alanı, bileşenleri ve sınırlılıkları ortaya konulmuştur.

\section{Yöntemin Uygulama Alanı; Ulusal Mimarlık Sergileri}

Mimarlar Odası tarafindan iki yıl ara ile periyodik olarak düzenlenen, Mimar Sinan'ın 400. ölüm yıldönümü anısına 1988'de ilki gerçekleştirilen Ulusal Mimarlık Sergisi ve Ödülleri, 80 sonrası Türkiye mimarisinin tanıtılması ve kamusallaştrılması amacı güden etkinlikler arasında öne çıkmaktadır. Etkinlik Mimarlar Odasının kendi belirlediği bu amacın dışında ülke mimarlığını koruma geliştirme ve özendirme görevini de üstlenmiştir. ${ }^{15}$ Özbay (2005) sergi ve ödül mekanizması oluşturulurken benzer ödül sistemleri-

\footnotetext{
9 Yapılan çalışmanın kısıtlılıkları ne- ${ }^{11}$ Lincoln ve Denzin 1994

deniyle makalede sadece 2008- ${ }^{12}$ Seale 2001.

2009 kataloğu üzerinden gerçek- ${ }^{13}$ Demirli 2007.

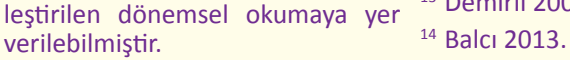

15 URL 1.
}

nin incelendiğini, incelenen örneklerin tümünde "ödül” ön planda olmasına rağmen ülke mimarlığının gelişimini izlemeyi olanaklı kılan Ulusal Mimarlık Sergisi ve Ödülleri'nde "sergi"nin ön plana alındığını belirtmiştir. ${ }^{16}$ Etkinlik, maddi değer taşımayan, sadece onurlandırma amacı güden bir ödüllendirme programı ve ödül alsın ya da almasın teknik şartnameye uyan tüm eserlerin yer aldığı bir sergi programı içermektedir. Sergi sonrasında hazırlanan kataloglar ise etkinliğe katılan tüm mimari ürünleri kayıt altına alarak düzenlendiği döneme ait geniş bir yapı envanteri ve kapsamlı bir arşiv sunmaktadır. Dolayısıyla etkinliğin sergi ayağının daha güçlü bir temsiliyet gücüne sahip olduğu söylenebilir.

Öte yandan Balamir (2005)'in de belirttiği gibi ortalama mimarlık üretiminin görünür standartlarıyla karşılaştrıldığında, ödül alan eserlerin Türkiye'nin çağdaş mimari anlayışını temsil gücü hayli sınırlıdır. ${ }^{17}$ Katılımın ağılıklı olarak İstanbul, Ankara İzmir gibi merkez kentlerden olması da etkinliğin temsiliyet gücü ile ilgili bir diğer tartşma konusudur. Ancak mimaride yeni akımların her zaman merkezde şekillenerek yayılıyor olması, diğer illerden katılımın yıldan yıla artyyor olması, katılan eserlerdeki mimari çeşitlilik, evrensellik ve kimlik adına iyimser bir çabanın izlenebiliyor olmas ${ }^{18}$ ve etkinliğin istikrarlı bir şekilde, ilk döneminden itibaren, her iki senede bir düzenleniyor olması temsiliyetle ilgili sorunların dönemden döneme azalmasını sağlamış, çalışma kapsamında bu sınırlılı̆ın göz ardı edilmesini olanaklı kılmıştır. Bu kapsamla Türkiye mimarlığının değerlendirmesinde veri kaynağı olarak kullanılabilecek potansiyele sahip kataloglar yöntemin uygulama alanı olarak seçilmiş, Türkiye mimarlığının bu kataloglar üzerinden değerlendirilebileceği öne sürülmüştür.

\section{Yönteminin Bileşenleri}

Yöntem, mimarinin ortaya çıktığı toplumun dinamikleri bağlamında biçimlendiği kabulü üzerine kurgulanmıştır. Dolayısıyla mimariyi dönemsel olarak anlamak, ancak bu verilerin gerçekçi ve bütünlüğü bozulmadan analiz edilmesi ile mümkün olabilir. Oysa toplumsal yapı sürekli bir devinim halindedir; yeniden şekillenmekte, değişmekte ve dönüşmektedir. Toplumsal-ideolojik bir alan olarak mimari ve kent, mekânsal anlamda toplumsal değişimin somutlaştğı ve görünür kılındığı en etkili ortamdır. Dolayısıyla toplumsal yapıyı şekillendiren her olgu mimariyi şekillendirmekte, mimarlığın dinamikleri haline gelmektedir. Bu nedenlerle toplumsal yapı verileri yöntemin temel bileşenleridir. Çok yönlü, karmaşık ve devingen yapıya sahip bu bileşenlerin parçalara ayrılması, mimarlığa ilişkin dönemsel değerlendirmelerde çözümlemeyi kolaylaştırılacaktır. Bu amaçla çalışmada toplumsal yapıyı, dolayısıyla mimarlığı, şekillendiren bileşenler; ekonomik, sosyokültürel ve politik bileşenler olarak tanımlanmış ve irdelenmiştir.

\footnotetext{
16 Özbay $2005 . \quad 17$ Balamir $2005 . \quad{ }^{18}$ Balamir 2005
} 


\section{Ekonomik Bileşenler}

Iktisadi alandaki değişimler, bireysel olarak insanı, yaşam koşullarını, beklentilerini dolayısıyla yaşamın geçtiği mimari ortamı ve mekânı etkilediği kadar kamusal mekânı da etkiler. Bu etki kentleşmeden, kent mekânının niteliğine; yapı malzemesinden, yapı teknolojisine ve kalitesine kadar pek çok alanda izlenir. Bilindiği gibi yapılaşma kararları, kentsel dönüşüm, toplu konut üretimi, kamusal mekânların tasarımı gibi mimarlık ve planlama ile ilgili pek çok konuda iktidar söz sahibidir. Dolayısıyla ülkenin ekonomik durumu iktidarın bu alandaki kararlarını ve yatırımlarını belirler. Türkiye hem dış etkenlerin, hem de iç dinamiklerin etkisiyle ekonomik alanda da yoğun olarak hissedilen sürekli ve çok yönlü bir değişim içerisindedir. Bu dönüşüm, ulusal ekonomi politikalarını, dönüşümleri, yeni ekonomik işlevlerin ortaya çıkışını, bu yeni gelişmelerin gereği olan yeni toplumsal kurumların oluşmasını, sınıf yapısındaki değişmeleri ve yeni bir yaşam tarzının oluşmasını içermektedir. ${ }^{19}$ Mimari ise bu oluşumların odağındaki mekansal ihtiyaçları karşılarken hem etkileyen hem de etkilenen olarak farklı biçimsel arayışları ve imgeleri gündeme getirir.

\section{Sosyokültürel Bileşenler}

Insanın kültürel evrimine paralel değişim gösteren sanat, aynı zamanda kültürün dönüşümüne katkıda bulunur ve sosyokültürel hareketliliği görünür kılar. Daha çok görsel yansımaları izlenen sosyokültürel hareketlilik, üretim, bilişim ve iletişim alanındaki evrensel gelişmelerin yanı sıra politik ve ekonomik olgular ile de sürekli etkileşim içerisindedir. Bu bakışla Türk modernleşme tarihinin de görsellik üstüne kurulduğunu ${ }^{20}$ söylemek mümkündür. 1980'lerden bu yana, Türkiye'de sanat ve mimari, Türk kültür ve siyasetinin laik, milliyetçi eski bekçileriyle onların liberal ya da İslamcı muhalifleri arasında giderek artan kutuplaşma bağlamında, ilerici-muhafazakâr, sol-sağ, modernist-gelenekçi gibi geleneksel karşıtlıkları bulanıklaştıran yeni sürpriz işbirlikleri içinde konumlandırılmaktadır. ${ }^{21}$ Dolayısıyla sosyokültürel hayat yönlendiren sanatsal etkinlikler de, tipkı mimari gibi, politika ile ideoloji odaklı bir ilişki kurmakta, aktörleri anlamlandırma, algılama ve kurgulama süreçlerinde etkileyerek mimariyi biçimlenmektedir.

\section{Politik Bileşenler}

Önceden belirlenmiş bir hedefe ulaşmak için hedef koyucular tarafindan öngörülen ya da hayata geçirilen tutum ve eylemler olarak tanımlanan politika mimarlığı etkileyen tüm etkenler içinde sahip olduğu belirleyici güçle özel bir konuma sahiptir. Özellikle politik bağlam açısından hedef koyanların kimler olduğu ve kimlik özelliklerinin neler olduğu (ideolojik, kültürel, ekonomik-sınıfları, inanç biçimleri vb.) mekânın mimari niteliklerini doğrudan etkilemektedir. ${ }^{22}$ Akalın'ın (2013) belirttiği gibi mimarlık her zaman

\footnotetext{
19 Tekeli 2007.

${ }^{20}$ Kahraman 2013
}

liderin gücüne işaret eden bir araç olarak görülmüş ${ }^{23}$ ve iktidarın gücü mekâna taşınarak, varlığı kentin her köşesinde belirli işaret ve şifrelerle hissettirilmiştir. Güç ve hâkimiyetin söz konusu olduğu bu ortamlarda, aktörler mekanı bir "meta" veya "ideolojik bir araç" olarak görmektedirler. ${ }^{24}$ Çünkü politika, ideolojinin uygulama için araçsallaştırdığı bir durumu işaret eder. İktidarı elinde tutan erk kendi ideolojik yapısını, politik kararlar ile uygulamaya koyar. Bu kararların mekânda nesnelleşmesi, topluma ve bireye aktarılması ise mimarlık üzerinden varlık bulur. Mimarinin genel kurgusu mekân üzerinedir; bu anlamda mekân, özellikle de kamusal mekân, iktidarın politik ideolojilerinin sergilendiği bir sahnedir. Iktidar bu sahnede kendi oluşturduğu mimari tarzı uygular ve bu tarzı yasalarla destekler. ${ }^{25}$ Cumhuriyet'in ilanından bu yana toplumsal yapının kendi iç dinamikleri dışında, devlet eliyle şekillenmiş olması politikanın özellikle kamu mimarisinin şekillenmesinde etkin bir role sahip olmasına neden olmuştur. Dolayısıyla politik yapı, mimariye yönelik dönemsel değerlendirmelerde en etkin bileşendir.

\section{Yöntemin Sınırlıııları}

Yöntem en nihayetinde mimarlığa ilişkin dönemsel bir değerlendirme yapmayı önermektedir. Sezgisel boyutlara sahip bu değerlendirmelerin tamamen nesnel verilere dayandırılamayacak olması yöntemin en önemli sınırıı̆ı̆ı olarak tanımlanabilir. Değerlendirmeler, dönemi temsil eden yapı/yapı gruplarının ve toplumsal yapıyı oluşturan bileşenlerin sunduğu nesnel verilerin bir arada yorumlanması üzerine kurgulanmıştır. Yorumlama öznel niteliğe sahip olmasına rağmen, değerlendirmelerin nesnel veriler üzerine konumlandırılması konuya ilişkin genel kanılar ile ilişkilendirilmesini sağlanmıştır. Bu kapsamla yöntemde; nitel araştırmaların özünü oluşturan sistemlilik bağlamında gruplama, kodlama, çakıştırma gibi aşamalar sistematik bir bütün içinde konumlandırılmış ve sosyal verilere dayanan değerlendirmelerde nesnel bilgi, olabildiğince, açığa çıkarılmıştır.

Yöntemin bir diğer sınırlılığı yapıya ilişkin tartışmaların kütle biçimlenmesi üzerine sürdürülmüş olmasıdır. Sergi kataloğunda yer alan yapı sayısının fazlalığı nedeniyle ortaya çıkan bu durum, yapıyı ifade etmek amaçı kullanılan çizim çeşitlerinin (plan, kesit, görünüş vb.) sınırlanmasını gerektirmiştir. Bu amaçla çalışmada sergi kataloğunda yer alan yapıların kütle biçimlenmesine ilişkin orijinal görsel dokümanlar kullanılmıştr. Taşıdığı değer ne olursa olsun her mimarlık ürününün bir simge olarak çevrenin dolayısıyla da bir kültür stoğunun içinde yer aldığı ve yüklendiği doğru ya da yanlış mesajlar ilettiği ${ }^{26}$ düşünüldüğünde mimari ürünün kütle biçimlenmesi üzerinden değerlendiril-

\footnotetext{
${ }^{23}$ Wilson 1998.

${ }^{24}$ Akalın 2013.
} 
mesi dönemin mimari eğilimlerini anlamak, üzerine düşünmek ve tartş̧mak için güçlü bir zemin yaratacaktır.

Öte yandan Ulusal Mimarlık Sergisi ve Ödülleri kataloglarında yer alan "Yapı Koruma-Yaşatma" başlı̆ı̆ altında yer alan projelerin restorasyona has teknik, sistematik, ilke ve kriterlerle; Türkiye dışındaki ülkeler için tasarlanan projelerin ise, o ülkenin kültürel, ekonomik, politik yapısı ile etkileşim içinde tasarlanmış olması bu dallara ilişkin projelerin yöntemin uygulama alanı dışında tutulmasına neden olmuştur.

\section{Yöntemin Ölçütleri}

Çalışmada sergi kataloğunda yer alan yapılar (mimari ürünler), kavramlar aracılığı ile tanımlanmıştır. Burada amaç nitel araşttrmalar bağlamında mimari ürünün tanımlanmasında ve açıklanmasında kullanılacak nesnel bir ölçüt belirlemektir. Mimari ürünün görsel özelliklerini tanımlamak amacıyla kullanılacak olan bu kavramlar, Türkiye'deki mimarinin modern ve modern sonrası süreçte gelişimi ile ilişkili üç ana başlıkta değerlendirilmiştir. Bunlar; yapının form özellikleri, üslupsal özellikleri ve anlamsal özellikleridir. Bu şekilde tanımlanan her kavram bilgiye dönüşsmüş, ${ }^{27}$ her bilgi değerlendirme kriteri olarak kullanılmıştır (Tablo 1). Ancak bu noktada, seçilen kavramların zamana bağı olarak farklılaşabileceği ya da değişime uğrayabileceği gerçeğine değinmek gerekmektedir.

\section{Yöntemin Genel Kurgusu}

Önerilen yöntem, nitel verilerin analizinde kullanılan Miles ve Huberman Modeli ile ilişkilendirilerek oluşturulmuştur. Miles ve Huberman Modeli'nde yapılan analiz: verilerin azaltılması, verilerin sunulması-sergilenmesi, sonuçların tasvir edilmesi ve doğrulanması olarak belirlenen üç temel aşamayı içermektedir. ${ }^{28}$ Verilerin azaltılması analiz boyunca devam eden bir aşamadır. Bu aşamada oldukça büyük hacme sahip veriler, sistematik bir düzenleme ile biçimlendirilir, ${ }^{29}$ gruplara ayrılır ve özetlenirler. Böylece nitel veri seti, üzerinde daha kolay çalışabilecek bir forma dönüştürülür. ${ }^{30}$ Araştırmacı verileri azalttrken kendine özgü stratejileri kullanabilir. Kodlama bu stratejilerden birisidir. Miles ve Huberman modelinde kodlama, analizin sonraki aşamalarına yön veren ilk ve en önemli adımdır. Kodlar, verilere ilişkin yönlendirici etiketlerdir. ${ }^{31}$ Kodlama ile veriler daha kolay bir şekilde kavramsallaştırılabilir. ${ }^{32}$ Kavramlaştırma, bir gözlemden, bir cümleden ya da bir paragraftan hareket ederek ilgili olay, düşünce ya da olguya isim verme sürecidir. ${ }^{33} \mathrm{Bu}$ anlamda veri azaltma ve kodlama yoruma açık işlemlerdir. Ancak verilerin kendi kapsamında değerlendirilmesi bu öznel yaklaşımı nesnelleştirir. Verilerin sunulması ise; verilerin düzenlenmesini, özetlenmesini ve böylece belirginleşmesini sağlar. Bu nedenle analizin her

\footnotetext{
27 Cordan 2002.

${ }^{28}$ Balcı 2013.

29 Baltacı 2017.

${ }^{30}$ Heritage 1984
}

\footnotetext{
${ }^{31}$ Miles ve Huberman 1984

${ }^{32}$ Keller 1995.

${ }^{33}$ Strauss ve Corbin 1990.
}

aşamasında kullanılır; ${ }^{34}$ sonuca ulaşılmasını ve verilerin yorumlanmasını kolaylaştırır. Verilerden anlamlı bir bütün oluşturulması ve araştırmanın ana sorunsalı olan sosyal olgunun çözümü için anlamlı bütüncül sonuçlara gidilmesi nitel veri analizinin son aşamasıdır. Bu aşamada araştırma$\mathrm{Cl}$, çeşitli anlam oluşturma stratejilerini kullanır, önermelerini geliştirir. Böylece veriler kümelenerek çeşitli veri birikimleri oluşturulur. ${ }^{35}$

Ekonomik, politik ve sosyokültürel bileşenler oldukça büyük hacme sahip verilerdir. Analiz edilebilmeleri için gruplara ayrılmalı, özetlenmeli ya da sadeleştirilmelidir. Bu amaçla çalışmada azaltma, sunum ve sonuç çıkarma işlemleri toplumsal yapı verilerinin sadeleştirilmesinde kullanılmıştır. Dolayısıyla yöntem, verilerin toplanması, gruplanması, azaltılması, çakıştırılması ve tartşılmasını içeren, birbirini takip eden, geri dönüşlere olanak sağlayan dört aşama içermektedir.

Yöntemin birinci aşaması; elde edilen verilerin incelendiği ve çeşitli özelliklerine göre gruplandığı, adlandırıldığı; modern ve modern sonrası sürece ilişkin kavramlar ile tanımlandığı/nitelendirildiği aşamadır. Ikinci aşama incelenen dönemde gerçekleşen olayların analiz edildiği aşamadır. Bu aşamada gruplama, özetleme ve kodlama ile bilgi kavramsallaştrılmıştr. Yöntemin üçüncü aşaması ilk iki aşamada elde edilen verilerin çakıştrıldığı, ve ilişkilendirildiği, her yapı grubuna ilişkin ayrı ayrı çıkarımlara ulaşılan aşamadır. Son aşamada ise grup değerlendirmeleri üzerinden bütüncül bir bakış açısı ile dönemsel genel bir değerlendirmeye ulaşılmaktadır (Şekil 1).

- Birinci Aşama/ Gruplama-Tanımlama: Ulusal Mimarlık Sergisi Kataloglarında yer alan, analiz edilecek mimari ürün sayısı oldukça fazladır. Dolayısıyla yapıları tekil olarak analiz etmek yöntemin uygulanabilirliği açısından sorunludur. Bu nedenle yöntemde, nitel araştırmaların çoğunda olduğu gibi, değerlendirilmek istenen döneme ait sergi kataloğunda yer alan, yöntemin sınırlılıkları çerçevesinde analiz edilebileceği belirlenen yapılar baskın görsel karakterini belirleyen form özelliklerine göre gruplanmış, yöntemin ölçütü olarak tanımlanan forma, üsluba ve anlam özelliklerine ilişkin kavramlar üzerinden tanımlanmış ve adlandırımıştır.

- ikinci Aşama/ Özetleme-Kodlama: Bu aşamada değerlendirilen dönemde gerçekleşen olaylar incelenmiş, derlenmiş ve döneme ilişkin toplumsal yapı verileri (ekonomik, politik, sosyokültürel) ve mimarlık alanındaki gelişmeler gruplandırılmıştır. Ülke gündemini meşgul eden, toplumsal yapıyı etkileyen bu olaylar, döneme ait gazetelerin, araştırma kurumlarının almanaklarının, ansiklopedilerin, mimarlar odası yayınlarının, gazetelerin, Mimarlar Odası sitesi arşiv verilerinin detaylı olarak taranması sonu-

${ }^{34}$ Balcı 2013. $\quad{ }^{35}$ Baltacı 2017. 


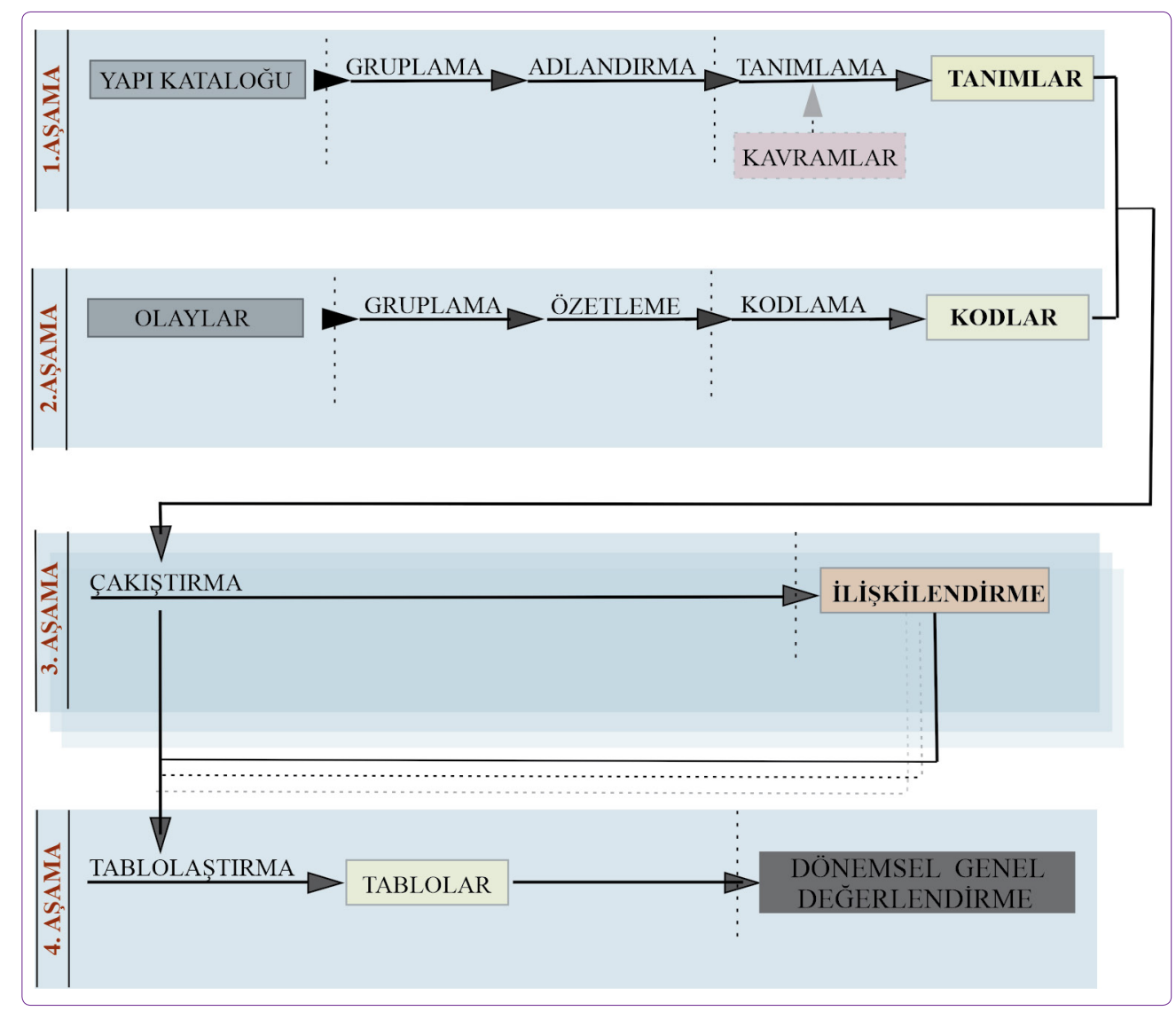

Şekil 1. Yöntemin aşamaları.

cu elde edilmiştir. Katalogda önceki iki yıla ait yapıların yer alması taramaların, serginin düzenlendiği yıldan önceki iki yıl için yapılmasını gerektirmiştir. Örneğin, 2010 kataloğundaki mimari ürünleri değerlendirmek için 2008 ve 2009 yıIına ait olaylar incelenmiştir. Ekonomik, politik, sosyokültürel ve mimari-kent olarak gruplanan bu olaylar, özetlenmiş; spot cümleler ile ifade edilmiştir. Sonrasında cümleler kodlama ile kavramsallaştrılmış, dönemin toplumsal yapısını oluşturan kavramlar olarak sıralanmıştır.

- Üçüncü Aşama/ Çakıştırma-ilişkilendirme: Verilerin çakıştrıldığı aşamadır. Çakıştırma her grup için ayrı ayrı yapılmış, her gruba ilişkin kavramlar toplumsal yapıyı tanımlayan ekonomik, politik, sosyokültürel ve mimari kodlar ile ilişkilendirilmiş, bu verilere referans verilerek değerlendirilmiş ve bazı tespitlere ulaşılmıştır. Bu tespitler nitel verilerle desteklenmiş olsa da değerlendirmeler öznel bir karaktere sahiptir. Eleştirel bir yaklaşımla oluşturulan bu değerlendirmeler, eleştirinin sahip olduğu nesnel ve öznel karakteri yansıtmakta, birbiri ile etkileşimli bir yorumlama sürecini içermektedir.

- Dördüncü Aşama/Değerlendirme: Dördüncü aşama ayrı ayrı her mimari ürün grubu için gerçekleştirilen çakıştırma işleminin dönemsel bir değerlendirme yapmaya olanak sağlamak amacıyla bir araya getirildiği aşamadır. Bu aşamada her grup için çakıştırılan veriler (mimari ürü- ne ilişkin kavramlar bağlamında oluşan tanımlamalar ve toplumsal yapı kodları) bir araya getirilerek tablolaştırılmış ve değerlendirilmiştir. Sayısallaştırma yolu ile genel değerlendirmelere ulaşmayı mümkün kılan bu tablolar üzerinden Türkiye mimarlığının belirtilen dönemlerde modern ve modern sonrası süreç bağlamında neyi temsil ettiğini, o dönemde nasıl bir mimari anlayışın egemen olduğunu saptamaya olanak sağlayacak bilgilere ulaşılmıştır. Bu bilgiler yöntemi kullanan kişinin yoğunlaşth̆̆ı alanla ve çalışmasının içeriğiyle ilişkili olarak farklı şekillerde ilişkilendirilebilir ve yorumlanabilir niteliktedir.

\section{Yöntemin Sınanması}

Dönemsel seçkilerin analizi için kullanılabilecek potansiyele sahip yöntem, 2008-2009 yıllarına ait mimari ürünlerin yer aldığı 12. Ulusal Mimarlık Sergisi ve Ödülleri Kataloğu (2010) ${ }^{36}$ üzerinde sınanmıştir. Bu kataloğun seçilme nedeni 2000 sonrasının, özellikle de ilk 10 yılının, Türkiye'de toplumsal yapıdaki değişimin farklı boyutlar kazandığı bir dönemi süreç anlamında tanımlamasıdır. Çünkü 2000'li yılların başından itibaren devlet ideolojisi, aynı siyasal erk tarafindan kurgulanmakta, etkinliği her alanda hissedilmektedir ve dönemsel bir süreklilik söz konusudur.

\footnotetext{
${ }^{36}$ Anonim 2011
} 
Tablo 1. Mimari ürüne ilişkin değerlendirmelerde kullanılan kriterler

\begin{tabular}{llll}
\hline Form özellikleri & & Üslupsal özellikleri & Anlamsal özellikleri \\
\hline Cepheye ilişkin; & Kütleye ilişkin; & Uluslararası & Anıtsal \\
Yalın & Dairesel & Çoğulcu & Mütevazi \\
Şeffaf-sağır & Kübik & Brütalist & Geleneksel \\
Dolu-boş & Prizmatik & Rasyonel & Gelenekselden kopuk \\
Monoton & Yatay & Eklektik & Yerel \\
Hareketli & Dikey & Çevre duyarlı & Yerelden kopuk \\
Tekrar & Simetrik & Analojik & Dışa açılma \\
Malzeme çeşitliliği & Asimetrik & Yöreselci & Iç̧e dönüş \\
& & & İdeolojik \\
& & & Heykelsi \\
\hline
\end{tabular}

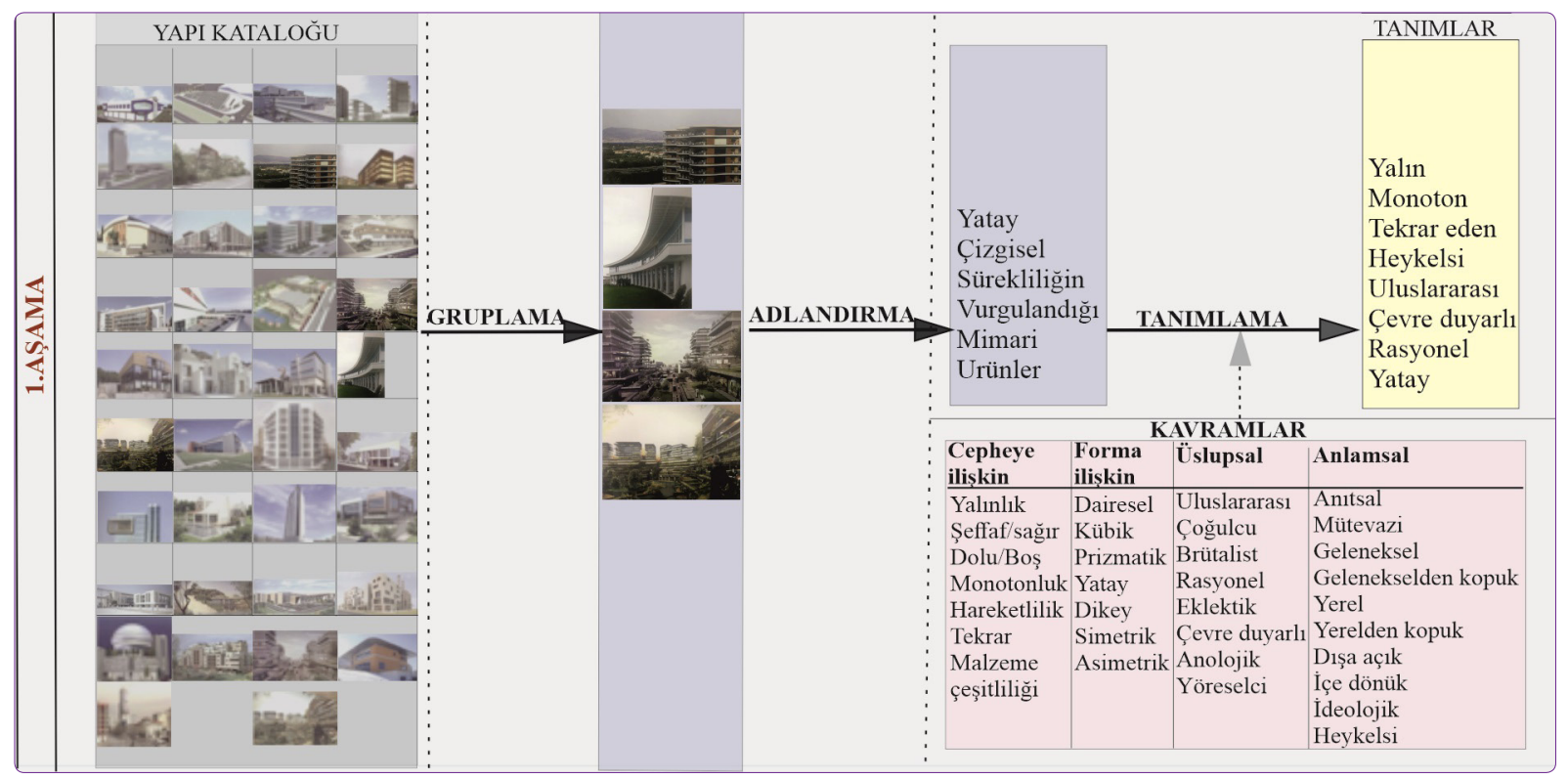

Şekil 2. Birinci aşama/ Gruplama-tanımlama

Dolayısıyla söz konusu dönem siyasal erkin ideolojisinin, daha önce olmadığı kadar, mekânda görünür hale geldiği, hem kentsel kamusal mekânın hem de mimari mekânın biçimlenişinde etkili olan düşünsel arka planın net olarak izlenebildiği bir döneme karşılık gelmektedir.

Yöntemin birinci aşaması/gruplama-tanımlama katalogda bulunan mimari ürünlerin gruplandığı, adlandıııldığı ve kavramlar üzerinden tanımlandığı aşamadır. Bu doğrultuda 12. Ulusal Mimarlık Sergi kataloğunda yer alan mimari ürünler analiz edilmiş, değerlendirmeye alınabilecek 103 mimari ürün olduğu belirlenmiştir. Bu mimari ürünler baskın görsel özelliklerine göre gruplanmış, 28 farklı gruba ulaşılmış, bunlar adlandırılmış ve yöntemin ölçütleri olarak belirlenen kavramlarla (Tablo 1) tanımlanmıştır (Şekil 2). Ancak 28 gruba ilişkin analizlerin tümüne makale içerisinde yer vermek pratik olarak mümkün değildir. ${ }^{37}$ Dolayısıyla

\footnotetext{
372010 Kataloğunda yer alan tüm yapı gruplarının analizi, makalenin üretildiği doktora tezinde yer almaktadır.
}

makale kapsamında diğerlerine örnek teşkil edecek, sadece bir analize yer verilmiş; "Yatay sürekliliğin vurgulandığı mimari ürünler" örnek analiz olarak incelenmiştir.

Bu grupta dört yapı yer almaktadır. Yapıların açıkta bırakılarak vurgulanan döşeme kalınlıkları en belirgin ortak özellikleridir. Bu kalınlık cephede yatay, çizgisel bir süreklilik sağlarken monoton ve yalın bir düzen yaratmıştı. Yapıların modern imajını güçlendiren bu düzen, heykelsi bir ifade sağlarken döneminin uluslararası mimari eğilimleriyle örtüşmektedir. Bu kapsamla grubun form özellikleri kütleleriyle ilişkili olarak yatay, cepheleri ile ilişkili olarak yalın, monoton; üslupsal özellikleri ile ilgili olarak uluslararası, rasyonel, çevre duyarlı; anlamsal özellikleri ile ilgili olarak ise heykelsi gibi kavramlarla tanımlanmıştır.

Yöntemin ikinci aşamasında/özetleme-kodlama 2008 ve 2009 yılına ilişkin ülke gündemini meşgul eden, toplumsal yapıyı etkilediği düşünülen olaylar daha önce belirtilen kaynaklar taranarak belirlenmiş, 'ekonomik', 'politik', 'sos- 
yokültürel' ve 'mimari-kente yönelik gelişmeler' başlıkları altında gruplanmış ve özetlenmiştir. Özetlenen haberler kodlanarak kavramsallaştrılmıştı. Buna göre 2008-2009 dönemi, ülkede yaşanan ekonomik krizin yerini uluslararası küresel bir krize bırakttğı ve bu krizin etkilerinin her alanda hissedilmeye başlandığı, özgürlüklerle ilgili tartı̧smaların gündeme gelmeye başladığı bir dönemdir. $A B$ ile uyum çalışmalarının $A B$ tarafindan yeterli bulunmadığı, ancak uyum çalışmalarının devam ettiği izlenmektedir. Hedef koyanlar ile Mimarlar Odası arasında kent mekanına ve mimariye ilişkin tartı̧̧maların gündeme geldiği dönemde, sanatsal üretime yön verme çabası içindeki iktidarın baskın ideolojisinin sanatta ve mimaride etkinliği hissedilmektedir. Sulukule Kentsel Dönüşüm Projesi, AKM tartısması, İstanbul Çevre Düzeni Planı, TOKi eleştirisi, ODTÜ'ye yıkım,
Taksim'e cami gibi olaylar bu etkinliğin ortaya çıkardığı tartı̧̧malı konular olarak dikkat çekmektedir. Yöntem kapsamında bu olaylar küresel kriz, özelleştirme, işsizlik, kültürel teşvik, eleştirel sanat vb. gibi kısa ifadelerle tanımlanmış ve kodlanmıştır (Şekil 3).

Yöntemin üçüncü aşamasında/çakıştırma-ilişkilendirme 28 gruba ilişkin tanımlamalar ayrı ayrı toplumsal yapı kodları ile çakıştırılarak ilişkilendirilmiştir. Buna göre "Yatay Çizgisel Sürekliliğin Vurgulandığı Mimari Ürünler" grubuna ilişkin tanımlar (yalın, monoton, çevre duyarlı, heykelsi, uluslararası, rasyonel, yatay) ve toplumsal yapı kodları (küresel kriz, özelleştirme, eleştirel sanat, kültürel teşvik, doğaya dönüş vb) çakıştırılmış ve yorumlanmıştır. 20082009 döneminin ekonomik kodları; küresel kriz, özelleștirme, işsizlik, bütçe açığı, İstanbul' un finans merkezi olması,

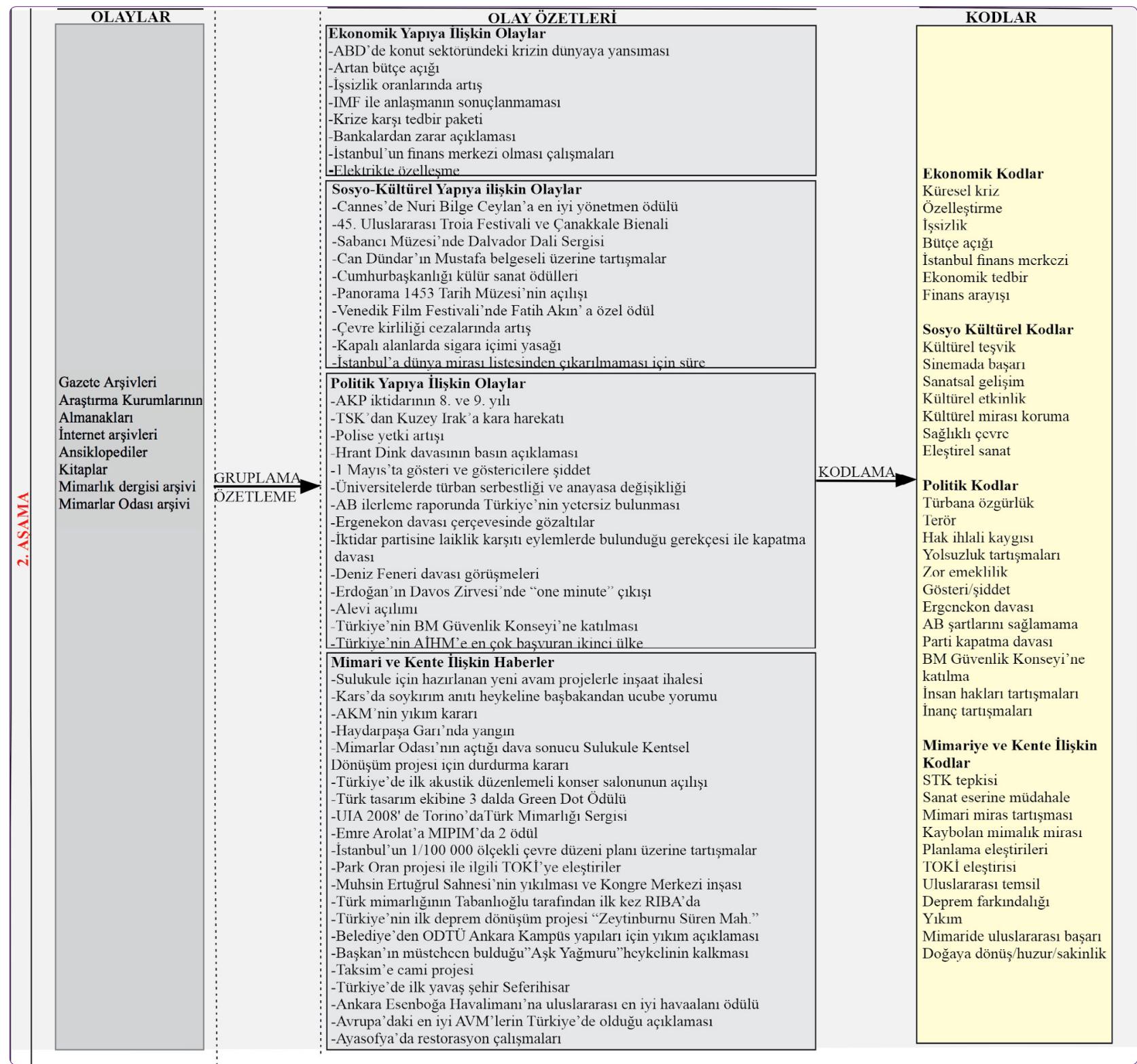

Şekil 3. İkinci aşama/ Özetleme-kodlama. 


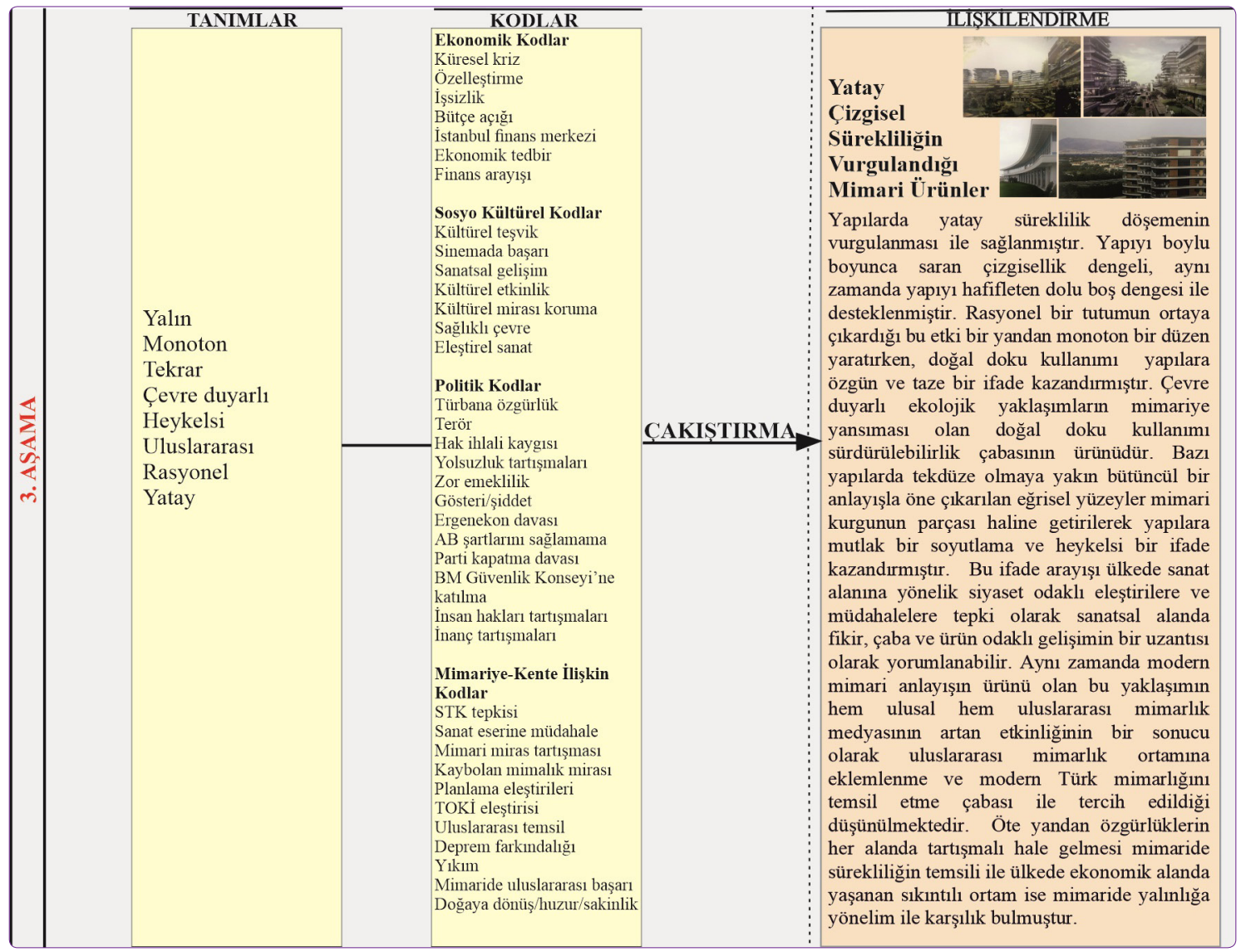

Şekil 4. Üçüncü aşama/ Çakıştırma.

ekonomik tedbirler ve finans arayışı; sosyo kültürel kodları kültürel teşvik, sinemada başarı, sanatsal gelişim, kültürel etkinlik, kültürel mirası koruma, sağlıklı çevre, eleştirel sanat; politik kodları türbanda özgürlük, terör, hak ihlali kaygısı, yolsuzluk tartş̧maları, zor emeklilik, gösteri-şiddet, Ergenekon davası, $A B$ şartlarının sağlanamaması, siyasal parti kapatma davası, BM Güvenlik Konseyi'ne katılma, insan hakları tartş̧maları, inanç tartş̧maları; mimariye kente ilişkin kodları ise STK tepkileri, sanata müdahale, mimari miras tartş̧maları, kaybolan mimarlık mirası, planlama eleştirileri, TOKi eleştirisi, uluslararası temsil, ödül, deprem farkındalığı, yıkım, mimaride uluslararası başarı, doğaya dönüş/huzur, sakinlik arayışı olarak belirlenmiştir. Bu kodlar yapı grubunu tanımlayan "yalın, monoton, yatay, uluslararası, rasyonel, çevre duyarlı, heykelsi kavramlarıyla ilişkilendirilmiş; kodların yapının fiziksel özelliklerini nasıl etkilediği değerlendirilmiştir. Örneğin ülkede ekonomik alanda yaşanan sıkıntılar mimaride yalınlığa yönelim ile; küreselleşme bağlamında dünya ile kurulan ilişki ve uluslararası mimarlık ortamına eklemlenme çabası modern mimariye gönderme yapan monoton, yalın cephe düzeni ile; artan çevre sorunları farkındalığı, ekolojik yaklaşımlar ve sürdürülebilirlik tartışmaları ise mimaride doğal doku kullanımı gibi çevre duyarlı yaklaşımlarla ilişkilendirilmiştir (Şekil 4).
Çalışma kapsamında yöntemin dördüncü aşamasında/ değerlendirme, üçüncü aşamada/çakıştırma gerçekleştirilen ilişkilendirmeler üzerinden dönemsel genel değerlendirmelere ulaşılmıştır. Ancak dönemdeki tüm yapı gruplarını tanımlayan kavramlar, toplumsal yapı kodları ve ilişkilendirmeler araştırma yapan kişinin odaklandığı konuyla ilişkili farklı şekillerde birbirleriyle ilişkilendirilebilir, farklı konulara ilişkin, farklı değerlendirmelere ulaşılabilir niteliktedir. ${ }^{38}$ Ayrıca bu noktada yöntemin sınandığı döneme ilişkin genel değerlendirmelere, 28 grup için yapılan çakıştırma aşamalarının tamamında ${ }^{39}$ elde edilen ilişkilendirmeler sonucu ulaşıldığını belirtmek gerekir. Buna göre toplumsal yapı kodlarına göre değerlendirilen dönem, genel anlamda ekonomik alanda sıkıntıların yaşandığı, yeni finans arayışlarının gündeme geldiği; sosyokültürel alanda yeni arayışların, gelişmelerin ve başarıların yanı sıra devletin ve iktidarın etkinliğini hissettirdiği ve bu etkinliğin sanatsal tartş̧maların merkezine alındığı; politik alanda ise $A B^{\prime} y e$ uyum sürecinin gündemdeolduğu, özgürlükler anlamında yeni açılımların yaşandığı ancak özgürlükler-

\footnotetext{
${ }^{38}$ Makale yöntemin genel kurgusuna odaklanmıştir. Bu nedenle verilerin analizine yönelik tablolara makale kapsamında yer verilmemiş, uygulayacak araştırmacının ilgi alanına göre çeşitlenebileceği belirtilmiştir.

${ }^{39}$ Makalede sadece tek bir yapı grubuna ilişkin çakıştırmaya yer verilmiş olmakla beraber makalenin üretildiği tez kapsamında tüm yapı grupları için ayrı ayrı çakıştırma aşaması gerçekleştirilmiştir.
} 


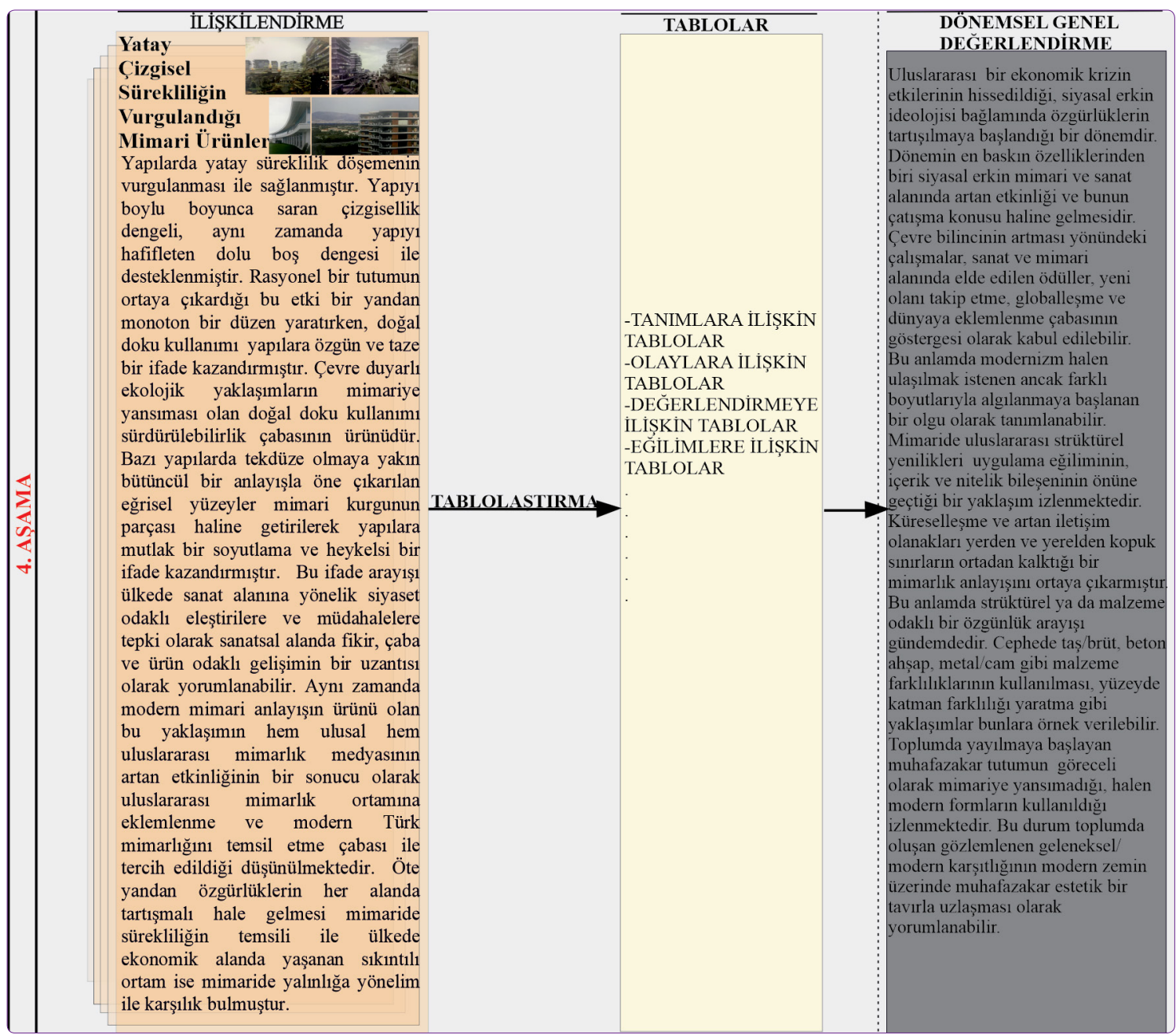

Şekil 5. Dördüncü aşama/ Değerlendirme.

le, insan haklarıyla ilişkili tartışmaların yaşandığı; mimari ve kent alanında ise deprem farkındalığının belirleyici ve biçimlendirici olduğu; mimarların gerek söylem, gerek tasarım gerekse üretim alanında Türkiye'yi uluslararası mimarlık ortamında başarıyla temsil etmeye çabaladıkları, küreselleşme bağlamında mimari alanda dünya ile ilişki kurdukları bir dönemdir. Bu dönemde katalogda bulunan yapı grupları incelendiğinde ${ }^{40}$ döneme ilişkin kapsamlı değerlendirmelere ulaşılmıştır (Şekil 5) Örneğin "yapılarda içerik ve nitelik bileşeninin geri planda tutulması ve uluslararası biçimsel denemelerin öne çıkarılması, iktidar ideolojisinin kamu mimarisinde gözlemlenmeye başlayan Selçuklu-Osmanlı mimarisi üzerinde sürdürdüğü biçim arayışının katalogda yer alan yapılarda çoğunlukla izlenmemesi, artan çevre duyarlııı̆ının ve ekolojik yaklaşımların doğal doku kullanımı ile mimariye yansıması, ekonomik kaynak yetersizliğinin mimaride yalınlığa yönelim ile

\footnotetext{
${ }^{40}$ Makaleye konu edilen tezde toplumsal yapının her yapı grubunun biçimlenmesindeki etkisi ayrı ayrı değerlendirilmiş, iliş̧i düzeyi bütüncül bir yaklaşımla tartışılmış, tanımlanmış ve döneme ilişkin genel değerlendirmelere ulaşılmıştır.
}

karşılık bulduğu" ulaşılan dönemsel genel değerlendirmelerden birkaçıdır.

Önerilen yöntem 12. Ulusal Mimarlık Sergisi ve Ödülleri Kataloğu üzerinde sınanmış, toplumsal yapı verilerinin mimari ve kent üzerindeki etkileri çözümlenmeye çalışılmıştr. Buna göre 2008-2009 dönemi iktidarın, hem sosyal- kültürel yapıyla hem de mimari ve kentle ilişkili etkinliğinin, dolayısıyla müdahale yetisinin, arttı̆ı bir dönemi işaret eder. Bahsi geçen dönemde sivil toplum kuruluşlarının, iktidarın ve halkın taraf olduğu tartş̧malara konu olan bu müdahalelerin mimariye yansımaları çoğunlukla kamusal mekânlar üzerinden okunmaktadır. Ancak ekonomik sıkıntlar, deprem, mimari alandaki uluslararası başarılar ve ödüller gibi pek çok olay, farklı yapı türlerinde, farklı biçimler üzerinden okunabilmektedir. Dolayısıyla bu ilişkileri tanımlayabilecek pek çok analiz yapmak mümkündür. Yöntem araştrma konusuna göre farklı verilerin birbiriyle ilişkilendirilebileceği bir içeriğe sahiptir. Ancak yöntem kapsamında değerlendirilen verilerin çoğunlukla nitel karaktere sahip olması değerlendirmelerin öznellikten tamamen soyutlanmasını engellemektedir. Dolayısıyla yöntem sistemlilik üzerine kurgulanmakla bera- 
ber büyük çaplı verilerin küçültülerek, ilişkilendirilebildiği ve böylece değerlendirilebilir forma getirildiği bir akış sunarken öznel değerlendirmelerin ötesinde nesnel değerlendirmelere de olanak tanıyan bir kurguya sahip olmuştur. Öte yandan yöntemin uygulama alanı olarak seçilen "Ulusal Mimarlık Sergisi Ödülleri Kataloğu" nun içerdiği mimari ürün çeşitliliği, ürünleri tanımlayan görsel dokümanların yeterliliği dönemsel değerlendirmelere olanak sağlayacak en kapsamlı mimari ürün arşivlerinden biri olduğu fikrini doğrulamıştır. Bu yönü ile etkinlik Türkiye mimarlığına ilişkin pek çok araştormaya konu olabilecek bir potansiyele sahiptir.

\section{Sonuç}

Rem Koolhaas bir söyleşisinde mimarlığın, iktidarsızlık ile mutlak iktidarın zehirli bir karışımı olduğunu söyleyerek mesleğin tehlikeli yanına dikkat çekmektedir. Koolhaas'a göre mimarlar fantezi ve hayaller kurarlar, fakat onların uygulanıp gerçekleşebilmesi başkalarına ve koşullara bağlıdır. ${ }^{41}$ Bu nedenle mimarlık nesnesi salt kendi gerçekliğinin dışında birçok anlam taşımaktadır. Bu anlamların bilimsel yöntemlerle analizi Koolhaas'ın da sözünü ettiği aktörlerin ve koşulların anlaşılmasını mümkün kılar. Bu nedenle mimarlıkta dönemsel değerlendirmeler büyük önem taşımaktadır. Araştırılan dönemin toplumsal, ekonomik, politik ve kültürel koşullarının nasıl bir mimarlık yarattı̆ını anlamak önemlidir. Çünkü mevcut sorunları saptamak yeni çözümler üretebilmek ve daha kaliteli kentsel kamusal çevreler yaratmak ya da dönemin üslup özelliklerini kavrayabilmek ancak böyle mümkün olabilecektir. Bu bağlamda geliştirilen yöntemin dönemsel değerlendirmeler için kullanılabilecek potansiyele sahip olduğu görülmüştür.

12.Ulusal Mimarlık Sergi Kataloğu'na yönelik dönemsel değerlendirmede nitel araştırmanın özünü oluşturan nesnel ve sistematik yaklaşım kullanılarak bu durum net olarak izlenebilmiştir. Örneğin, bu dönemde ülkede sanat alanına yönelik siyaset odaklı eleştirilere ve müdahalelere tepki olarak sanat ve mimari gibi alanlarda fikir, çaba ve ürün odaklı bir gelişim izlenmiş, uluslararası mimarlık ortamına eklemlenme çabası bu gelişimi uluslararası ortamlarda görünür hale getirmiştir. Bu ortam katalogda bulunan yapıların bazılarında heykelsi bir ifade arayışı ile somutlaşırken; artan çevre duyarlılı̆ı katalogdaki mimari ürünlerin pek çoğunda doğal doku kullanımı ile karşılık bulmuştur. Dönemsel değerledirmeden de anlaşıldığı üzere, toplumsal yapının mimari üzerindeki etkisi ve bunun yapıların biçimsel arayışlarında okunabiliyor olması mimarlığın üzerinde bulunduğu coğrafyanın toplumsal, kültürel, ekonomik ve politik olaylarının mekânsallaştığı bir eylem olduğunu kanıtlanmaktadır.

Ancak sistemlilik üzerine kurgulanan, nesnel verilerle desteklenen çalışma kapsamında önerilen bu yöntemle mimarlığı tüm yönleriyle analiz etmenin, yorumlamanın ve

\footnotetext{
${ }^{41}$ Koolhaas 1996.
}

değerlendirmenin mümkün olduğu söylenemez. Yapıları mimari olarak temsil eden çizimler çeşitlendirilebileceği gibi kavramlar ve kavramlarla ilişkili ölçütler zamanla ya da araştırmacının odaklandığı konuyla ilişkili olarak çeşitlenebilir, değişebilir ya da dönüşebilir. Dolayısıyla yöntem, uygulayan araştırmacının uygulayacağı objektif kriterlere ve tekniklere bağlı olarak geliştirilebilme ve farklı sorunların çözümüne uyarlanabilme olanağına sahiptir.

\section{Kaynaklar}

Akalın, A. (2013) “iktidar Kimliği ve Günümüz Adalet Sarayları", Mimarlık, 370, ìstanbul, 20-22.

Akyıldız, A. (2007) "Mekân Tasarımında Anlam Üretme Sürecinin Göstergebilim ve Dilbilim Bağlamında İrdelenmesi", VIII. AISV-IAVS Uluslararası Görsel Göstergebilim Kongresi, “Görünürün Kültürleri" Bildiri Kitabı, T.C. İstanbul Kültür Üniversitesi, İstanbul, 29 Mayıs-2 Haziran, 513-521.

Anonim (2011) 2010 Mimarlar Odası 12.Ulusal Mimarlık Sergisi ve Ödülleri, yay.haz. Cengizkan, M., Mimarlar Odası Yayınları, Ankara.

Balamir, A. (2005) “Türkiye'nin Ulusal Mimarlık Sergisi ve Ödülleri", Ulusal Mimarlık Sergisi ve Ödülleri, Türkiye 1988-2004, Mimarlar Odası Yayını, İstanbul, 8-10.

Balcı, A. (2013) Sosyal Bilimlerde Araştırma (10. Baskı) Pegem Yayıncilık, Ankara.

Baltacl, A. (2017) "Nitel Veri Analizinde Miles-Huberman Modeli" Ahi Evran Üniversitesi Sosyal Bilimler Enstitüsü Dergisi (AEÜSBED), Cilt 3, Sayı 1, 1-15

Bozdoğan, S. (2011) "Modern Türkiye'de Sanat ve Mimari: Cumhuriyet Dönemi", Türkiye Tarihi "Modern Dünyada Türkiye 1839-2010", Cilt 4, ed. Kasaba, R., çev. Bilgin, Z., Kitap Yayınevi, İstanbul, 451-508.

Cordan, Ö. (2002) Mimari Formun Kavramsal Analizi, Doktora Tezi, Karadeniz Teknik Üniversitesi, Fen Bilimleri Enstitüsü, Trabzon.

Demirli, C. (2007) E-Portfolyo Öğretim Sürecinin Öğrenenlerin Tutumları ve Algıları Üzerine Etkisi, Doktora Tezi, Fırat Üniversitesi, Sosyal Bilimler Enstitüsü, Elazı̆̆.

Habermas, J. (1994) Postmodernizm, Modernlik: Tamamlanmamış Bir Proje (2.Baskı), çev. Zeka, N., Kıyı Yayınları, ìstanbul.

Hasol, D. (2017) 20.yy Türkiye Mimarlığı, Yem Kitapevi, İstanbul.

Heritage, J. (1984) Garfirikela nd Ethnomethodology, Cambiridge: Polity Press.

Karaibrahimoğlu, S. ve Usta, A. (2013) The Political Life and Architecture in Turkey in 2000s, Politics in the History of Architecture as Cause and Consequence, ARCHIST'13, İstanbul, MSGSÜ Yayınları, 87-106.

Karaibrahimoğlu S. (2014) Modernizm Bağlamında 2000'li Yıllarda Türkiye Mimarlığı; Ulusal Mimarlık Sergileri Üzerinden Bir Değerlendirme, Doktora Tezi, Karadeniz Teknik Üniversitesi, Fen Bilimleri Enstitüsü, Trabzon.

Kahraman, H.B. (2013) Türkiye'de Görsel Bilincin Oluşumu Türkiye'de Modern Kültürün Oluşumu 1, Kapı Yayınları, İstanbul.

Kahvecioğlu, H. (2011) “Ulusal Mimarlık Sergisi ve Türkiye'de Mimarlık: XII. Dönem Üzerinden Değerlendirmeler", 2010 Mimarlar Odası 12. Ulusal Mimarlık Sergisi ve Ödülleri, ed.: Cengizkan, M., Mimarlar Odası Yayınları, Ankara, 82-84. 
Keller, U. (1995) Qualitative Data Analysis: Theory, Methods and Practice for Researchers. London: Sage.

Koolhaas, R. (1996) Öğrencilerle Söyleşiler, çev: Nazım Dikbaş, Yem Yayınları, İstanbul.

Lincoln Y.S. ve Denzin N.K. (1994) Handbook of Qualitative Research. CA: Sage.

Miles, M. B. ve Huberman, A.M. (1984) Qualitative Data Analysis. London, Sage Publications, Inc

Özbay, H. (2005) “1988'den 2004'e Ulusal Mimarlık Sergisi ve Ödülleri", Ulusal Mimarlık Sergisi ve Ödülleri, Türkiye 19882004, Mimarlar Odası Yayını, İstanbul, 14-15.

Seale, C. (2011) Researching Society and Culture, London, Sage Publications, Inc

Soygeniş, M. (1999) 2000'e Girerken Türkiye'de Mimarlık, Yıldız Buluşması Mimarlık Uygulamaları Tartışmaları, Tasarım Yayın
Grubu, İstanbul,7-11.

Strauss, A. ve Corbin, J. M. (1990) Basics Of Qualitative Research: Grounded Theory Procedures and Techniques. Thousand Oaks, CA, US: Sage Publications, Inc.

Tanyeli, U. (2005) "Ulusal Mimarlık Sergisi ve Ödülleri: Anonim Dünyasında Düzen Arayışı", Ulusal Mimarlık Sergisi ve Ödülleri, Türkiye 1988-2004, Mimarlar Odası Yayını, İstanbul, 18-21.

Tekeli, İ. (2007) “Türkiye'de Mimarlığın Gelişiminin Toplumsal Bağlamı", Modern Türk Mimarlığı, TBMM Mimarlar Odası, Ankara, 13-37.

Wilson, P. J. (1998) The Domestication of the Human Species, Yale Universty Press, New Haven

\section{Internet Kaynakları}

URL- 1, http://www.mo.org.tr/ulusalsergi/, [Erişim tarihi: 5 Ağustos 2014]. 